\title{
Threonine metabolism in sheep
}

\section{Threonine catabolism and gluconeogenesis in mature Blackface wethers given poor quality hill herbage}

\author{
By A. R. EGAN*, J. C. MACRAE† AND C. S. LAMB \\ The Hill Farming Research Organisation, Bush Estate, Penicuik, Midlothian EH26 OPY, \\ Scotland
}

(Received 5 November 1981 - Accepted 23 November 1982)

1. In three experiments, mature Blackface wethers were given freeze-stored Agrostis festuca herbage by continuous feeder.

2. In Expt 1 , on separate occasions [U-14 C]threonine, [U-14 C]glucose and $\mathrm{NaH}^{14} \mathrm{CO}_{3}$ were infused over $12 \mathrm{~h}$ periods to obtain estimates of irreversible loss rate (ILR) of threonine, glucose and carbon dioxide in the plasma and of the exchange of $\mathrm{C}$ between these metabolites.

3. In Expts 2 and 3, during periods when glucose and threonine metabolism were examined, glucose loss across the kidneys (23-29 $\mathrm{g} / \mathrm{d})$ was induced by infusion of phloridzin.

4. Results from the four sheep used in Expts 1 and 3 are presented as three-pool models. They indicate that threonine ILR $(7.8 \mathrm{~g} / \mathrm{d} ; 3.1 \mathrm{~g} \mathrm{C} / \mathrm{d})$ was approximately three times the estimated rate of absorption of exogenous threonine $(1 \mathrm{~g} \mathrm{C} / \mathrm{d})$. Glucose ILR was approximately $76 \mathrm{~g} / \mathrm{d}$ (mean $\pm \mathrm{SE} ; 30 \cdot 3 \pm 0.57 \mathrm{~g} \mathrm{C} / \mathrm{d})$. Only $0.3 \%$ of the glucose-C $(0.09 \mathrm{~g} / \mathrm{d})$ was derived directly from threonine-C (i.e. $3 \%$ of the threonine-C ILR). Bicarbonate ILR was $170 \pm 7.3 \mathrm{~g} \mathrm{C} / \mathrm{d}$, and glucose contributed $11.1 \pm 3.52 \mathrm{~g} \mathrm{C} / \mathrm{d}$ to this, accounting for $51 \pm 4.4 \%$ of glucose-C ILR. Threonine contributed $0.20 \pm 0.026 \mathrm{~g} \mathrm{C} / \mathrm{d}$ to the bicarbonate-C ILR, accounting for only $6.4 \pm 0.87 \%$ of the threonine-C ILR.

5. When, in Expts 2 and 3, phloridzin was infused, glucose ILR was increased by $28 \pm 1.5 \%$ and bicarbonate ILR was increased by $13 \pm 2.4 \%$. Threonine ILR $(3 \cdot 1 \mathrm{~g} \mathrm{C} / \mathrm{d})$ was not increased, but the metabolic distribution of threonine-C was altered. The transfer of threonine-C into glucose and $\mathrm{CO}_{2}$ was increased by 39 and $69 \%$ respectively to 0.125 and $0.45 \mathrm{~g} \mathrm{C} / \mathrm{d}$, accounting for 4 and $13 \%$ of the threonine ILR respectively.

6. Both technical and metabolic considerations which affect interpretation of these results in terms of rates of catabolism of threonine and of quantitative estimates of gluconeogenesis from threonine are discussed.

There is growing evidence that the proportional amounts of certain essential amino acids (EAA), particularly the sulphur-amino acids and threonine, absorbed from the small intestine are lower than is found in deposited animal protein (Egan \& Walker, 1975; Egan, 1980 ) and it has been suggested that the availability of these specific nutrients may be limiting the rate of protein deposition (Fennessy, 1976).

The carbon atoms of the glycogenic amino acids, which include threonine, can also be used to synthesize glucose or glycolytic intermediates which may ultimately be oxidized in energy-yielding processes. Any diversion of threonine to pathways for complete oxidation or for glucose production will reduce further the amount of threonine available for protein synthesis.

The involvement of threonine in these three pathways has been examined in adult wether sheep which have been maintained in a slight energy and nitrogen deficit such that an extra demand for glucose and energy might be exerted on the metabolism of EAA. In addition, a further stress was placed on the animals' glucose economy by treatment with phloridzin, which inhibited the reabsorption of glucose by the kidneys and resulted in glucose elimination in the urine. A preliminary report of part of this study has already been made (Egan \& MacRae, 1978).

Present addresses: * School of Agriculture and Forestry, University of Melbourne, Victoria, Australia. $\dagger$ The Rowett Research Institute, Bucksburn, Aberdeen AB2 9SB, Scotland. 
EX PER I MENT A L

Sheep and diets

Mature Blackface wethers $(43-48 \mathrm{~kg}$ ) were held for the duration of each experiment in metabolism cages and received daily $650 \mathrm{~g}$ dry matter (DM) of freeze-stored Agrostis festuca herbage (thawed but not chopped; DM content $300-350 \mathrm{~g} / \mathrm{kg}$; $\mathrm{N}$ content $12 \mathrm{~g} / \mathrm{kg}$ DM; DM digestibility coefficient $0 \cdot 36$ ) by means of continuous belt-type feeders. Three experiments were performed and each animal had a polyethylene catheter inserted into each external jugular vein at least $24 \mathrm{~h}$ before the commencement of each experiment. Attempts were made to place the sampling catheter in or near the heart.

\section{Infusions}

Radioactive materials and phloridzin. D-[U-14 C]glucose, D-[2- $\left.{ }^{3} \mathrm{H}\right] \mathrm{glucose}, \mathrm{L}-\left(\mathrm{U}-{ }^{14} \mathrm{C}\right]$ threonine and $\mathrm{NaH}^{14} \mathrm{CO}_{3}$ were obtained from Amersham International (Amersham, Bucks). Nominal specific activities on supply were all $100-500 \mathrm{mCi} / \mathrm{mmol}$. Each substance was prepared for infusion in sterile physiological saline $(9 \mathrm{~g}$ sodium chloride/1) containing approximately $100 \mathrm{mg}$ glucose or threonine carrier/l. Each solution was calculated to supply $0 \cdot 16-$ $0.18 \mu \mathrm{Ci} / \mathrm{min}{ }^{14} \mathrm{C}$ or $0.30 \mu \mathrm{Ci} / \mathrm{min}{ }^{3} \mathrm{H}$, infusion rates being $0.30-0.40 \mathrm{ml} / \mathrm{min}$.

Pure phloridzin extract (British Pharmaceutical) was dissolved in sterile physiological saline, to provide a concentration of $0.5-1.0 \mathrm{mg} / \mathrm{ml}$, and infused at rates of $0.3-0.4 \mathrm{ml} / \mathrm{min}$ in Expts 2 and 3.

\section{Experimental procedures}

Design. Three experiments were performed. In Expt 1 measurements were made of the irreversible loss rate (ILR) of threonine, glucose and carbon dioxide, and of the transfer of $\mathrm{C}$ between these three metabolites when two sheep were given their basal ration. In Expt 2 glucose ILR was measured before and during a period when four sheep received an infusion of phloridzin, which blocked resorption of glucose across the kidney tubules and so caused the animals to pass glucose (approximately $25 \mathrm{~g} / \mathrm{d}$ ) in their urine. In Expt 3 the sequence of measurements performed in Expt 1 was carried out on two sheep before and during the phloridzin infusions.

Procedures. In Expts 1 and 3, infusions of radiotracers were made in a set sequence on three different occasions in each experiment. Infusions made on the first occasion were $\left[2-{ }^{3} \mathrm{H}\right]$ glucose $+\left[\mathrm{U}-{ }^{14} \mathrm{C}\right]$ glucose; on the second occasion $\left[2-{ }^{3} \mathrm{H}\right]$ glucose $+\left[\mathrm{U}-{ }^{14} \mathrm{C}\right]$ threonine; and on the third occasion $\left[2-{ }^{3} \mathrm{H}\right]$ glucose and $\mathrm{NaH}^{14} \mathrm{CO}_{3}$. This sequence reduced the likelihood of interference of labelled metabolite from previous infusions. At least $72 \mathrm{~h}$ was allowed between infusions and within this interval the specific radioactivities (SR) of all substances to be assayed had returned to background. The infusions of ${ }^{3} \mathrm{H}$-labelled glucose allowed monitoring of, and an internal correction for, any day-to-day variation in glucose kinetics.

Procedures adopted were as follows:

Expt 1. On each occasion infusions (intravenous) of the appropriate radiotracer substance were made continuously by peristaltic pump over $12 \mathrm{~h}$. Blood samples $(5-15 \mathrm{ml})$ were drawn from the other catheter at hourly intervals during the 8 th-12th $h$ of infusion.

Expt 2. The infusions of [U-14C]glucose were made continuously for $24 \mathrm{~h}$. Phloridzin treatment commenced with a priming dose $(20 \mathrm{mg}$ injected via jugular) $12 \mathrm{~h}$ after commencement of the tracer infusion. The phloridzin infusion $(9.7 \mathrm{mg} / \mathrm{h})$ was continued for a further $12 \mathrm{~h}$. Blood samples were drawn during the $8 \mathrm{th}-12 \mathrm{th}$ h of isotope infusion (i.e. before phloridzin infusion) and also during the 20 th-24th $h$ of isotope infusion. 
Expt 3. On each occasion infusions of radioisotope tracer and of phloridzin (priming dose $20 \mathrm{mg}$; infusion $17.8 \mathrm{mg} / \mathrm{h}$ ) were made as in Expt 2 for each set of isotopes used as in Expt 1. Blood samples were drawn in the 8 th-12th and 20 th-24th $h$ of the isotope infusions.

\section{Samples}

Urine samples were collected daily throughout each experiment, but during Expt 3, urination was induced at $8,12,20$ and $24 \mathrm{~h}$ after commencement of isotope infusion. This provided urine samples coinciding with the two blood sampling periods (i.e. at plateau) before and during phloridzin infusion.

\section{Analyses}

A subsample (3-4 $\mathrm{ml}$ ) of whole blood and urine was taken immediately on sampling into a McCartney bottle for determination of $\mathrm{CO}_{2}$ SR by the method of Leng \& Leonard (1965) as modified by MacRae \& Wilson (1978). Blood plasma obtained by centrifuging whole blood $(5-7 \mathrm{ml})$ was used for the assay of glucose and threonine SR. Glucose concentration was determined by the method of Huggett \& Nixon (1957). Glucose SR was determined on the pentaacetate derivative extracted from plasma according to the method of Jones (1965), the pentaacetate was taken up in Instaflor II (Packard Instrument Company) and radioactivity assayed by liquid scintillation counting. Threonine SR was determined on the effluent from ion exchange column chromatography using NE260 Scintillant (New England Nuclear). Deproteinized plasma $(2 \mathrm{ml})$ was first eluted through a Durrum chromobead resin column on a Locarte amino acid analyser using a 3-step lithium citrate buffer system, buffer 1 being adjusted to $\mathrm{pH} 2.87$ to provide effective separation of serine and threonine. The analyser was fitted with a stream splitter which provided approximately $16 \%$ of the effluent for amino acid identification and assay. The remainder was collected in successive 2-ml fractions. Threonine eluted at $47 \mathrm{~min}$. Each fraction around the threonine peak was divided into duplicate $1 \mathrm{ml}$ portions for counting in NE260 Scintillant. The samples were counted until 1000 counts per min above background had accumulated. Recovery and effectiveness in assaying the threonine $\mathrm{SR}$ was checked by eluting radioactive threonine added to a standard amino acid mixture in TCA-deproteinized plasma; $98 \pm 3 \%$ of added radioactivity was recovered in three successive fractions, and the fraction with the highest activity had an SR of $101 \cdot 7 \pm 2.8 \%$ of the known threonine SR. Each threonine SR estimate given in the Tables was based on at least five separate blood samples taken over the 'plateau' period.

\section{Calculations}

All results presented here were calculated relative to the mean 'plateau' SR values obtained over the period $8-12 \mathrm{~h}$ after commencement of the tracer infusions. ILR of glucose, threonine and $\mathrm{CO}_{2}$ were determined from the relationship between infusion rate and SR in plasma. Transfer quotients were determined from the relationship of SR of secondary pool:SR of primary pool where the three tracers were infused. The values obtained for the three-pool model given in Fig. 1 and Table 5 were calculated from the ILR and transfer quotients for the various metabolites by matrix analysis of the twelve simultaneous equations given by Nolan et al. (1976), except that there was no detectable transfer of activity to threonine when either $\left[\mathrm{U}-{ }^{14} \mathrm{C}\right]$ glucose or $\mathrm{NaH}^{14} \mathrm{CO}_{3}$ was infused and so these two transfer quotients were restrained to zero.

\section{RESULTS}

\section{Expt 1}

Intake of Agrostis festuca varied little between days for each sheep. All sheep consumed approximately $650 \mathrm{~g} \mathrm{DM} / \mathrm{d}$ of Agrostis festuca (see Tables 1 and 2). Using values from the 


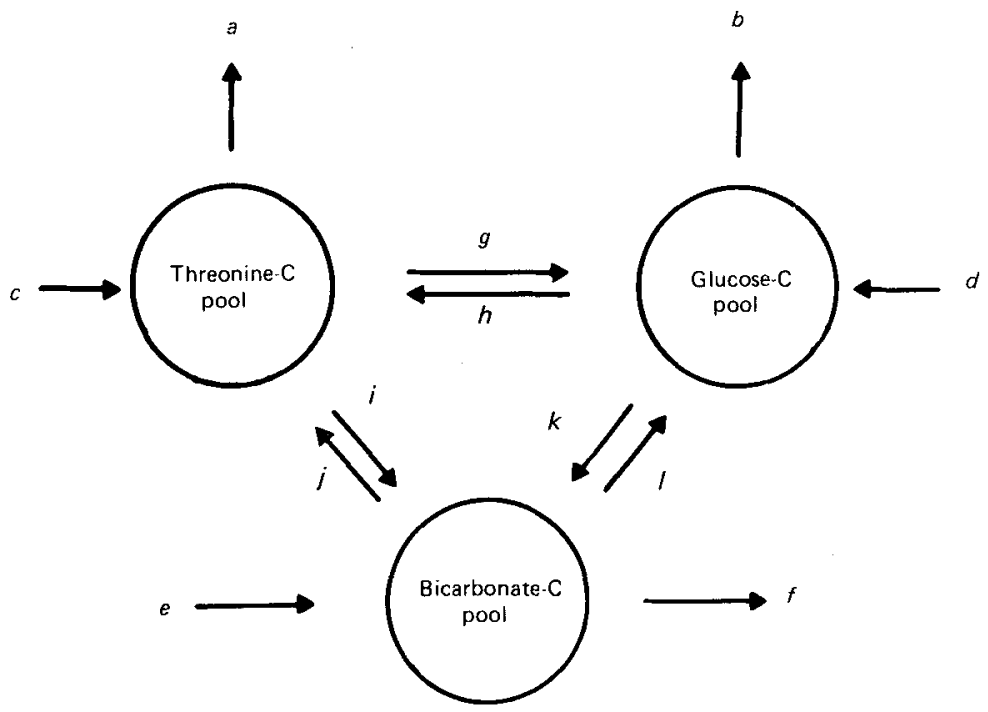

Fig. 1. Three-pool open-compartment model describing the movement of carbon between the plasmathreonine, plasma-glucose and blood-bicarbonate pools. Values for $a-l(\mathrm{~g} \mathrm{C} / \mathrm{d})$ are given in Table 5 .

Table 1. Expt 1. Specific radioactivities of carbon in glucose, threonine and carbon dioxide in jugular blood during infusion of ${ }^{14} \mathrm{C}$-labelled glucose, threonine or sodium bicarbonate

(Values are for two sheep during the period 8-12 h after commencement of infusion)

\begin{tabular}{|c|c|c|c|c|c|c|}
\hline \multirow[b]{2}{*}{ Tracer infused } & \multirow[b]{2}{*}{ Sheep no. } & \multirow[b]{2}{*}{ Intake } & \multirow{2}{*}{$\begin{array}{l}\text { Infusion } \\
\text { rate } \\
(\mu \mathrm{Ci} / \mathrm{min})\end{array}$} & \multicolumn{3}{|c|}{$\begin{array}{l}\text { Specific activity of } \\
\text { metabolite-C } \\
(\mathrm{mCi} / \mathrm{g} \mathrm{C})\end{array}$} \\
\hline & & & & Threonine & Glucose & $\mathrm{CO}_{2}$ \\
\hline$\left[\mathrm{U}-{ }^{14} \mathrm{C}\right]$ threonine & $\begin{array}{r}443 \\
74\end{array}$ & $\begin{array}{l}638 \\
654\end{array}$ & $\begin{array}{l}0.157 \\
0.139\end{array}$ & $\begin{array}{l}75 \cdot 1 \\
62 \cdot 0\end{array}$ & $\begin{array}{l}0 \cdot 25 \\
0 \cdot 21\end{array}$ & $\begin{array}{l}0.08 \\
0.09\end{array}$ \\
\hline $\mathrm{NaH}^{14} \mathrm{CO}_{3}$ & $\begin{array}{r}443 \\
74\end{array}$ & $\begin{array}{l}649 \\
650\end{array}$ & $\begin{array}{l}0.153 \\
0.156\end{array}$ & $\begin{array}{l}\text { ND } \\
\text { ND }\end{array}$ & $\begin{array}{l}0 \cdot 26 \\
0 \cdot 24\end{array}$ & $\begin{array}{l}1 \cdot 42 \\
1 \cdot 39\end{array}$ \\
\hline$\left[\mathrm{U}^{-14} \mathrm{C}\right] \mathrm{glucose}$ & $\begin{array}{r}443 \\
74\end{array}$ & $\begin{array}{l}637 \\
640\end{array}$ & $\begin{array}{l}0.224 \\
0.225\end{array}$ & $\begin{array}{l}\text { ND } \\
\text { ND }\end{array}$ & $\begin{array}{l}10 \cdot 6 \\
11 \cdot 2\end{array}$ & $\begin{array}{l}0.98 \\
0.87\end{array}$ \\
\hline
\end{tabular}

ND, below the limits of radioactivity detectable at threonine concentration in eluted fraction, and regarded as zero in further calculations.

digestion of nitrogen in sheep given the same Agrostis herbage (MacRae et al. 1979) it can be calculated that these animals would apparently absorb less than $1 \mathrm{~g}$ of threonine-C/d from their small intestine. This calculation is based on the fact that according to the regression equations given by MacRae et al. (1979), sheep consuming $650 \mathrm{~g} \mathrm{DM} / \mathrm{d}$ of Agrostis festuca having an $\mathrm{N}$ content of $12 \mathrm{~g} \mathrm{~N} / \mathrm{kg}$ DM would absorb approximately $7 \mathrm{~g}$ non-ammonia $\mathrm{N} / \mathrm{d}$ from their intestine. Assuming that the threonine content of non-ammonia $\mathrm{N}$ which disappears from the small intestine of sheep given a roughage diet is $50-55 \mathrm{~g} / \mathrm{kg}$ non-ammonia $\mathrm{N}$ (MacRae et al. 1972), then the apparent absorption of threonine-C would be $0.9-0.95 \mathrm{gC} / \mathrm{d}$.

The SR of the primary-pool glucose, threonine and $\mathrm{CO}_{2}$ measured during the 8th-12th $\mathrm{h}$ 
Table 2. Expt 1. Feed intake, and values for irreversible loss and transfer quotient of carbon in blood-free threonine, glucose and carbon dioxide in two sheep given Agrostis festuca

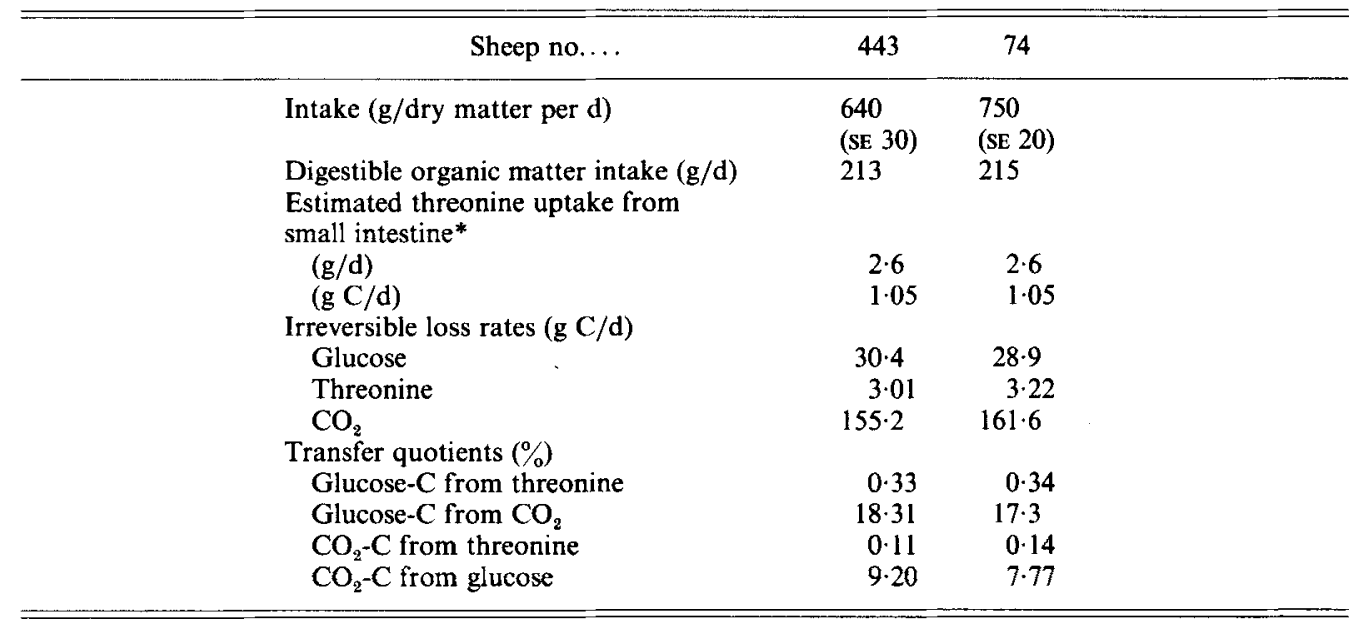

* Estimated from the disappearance of non-ammonia nitrogen from small intestine in sheep given Agrostis festuca in separate experiments (see text and MacRae et al. 1979).

of infusion of the respective isotopes in each sheep exhibited some variability but showed no significant slope with time and so means of each set of values were used to calculate the ILR values (Table 2). Results were consistent between the two sheep on this diet, indicating ILR of approximately $3 \mathrm{~g}$ threonine-C/d, $30 \mathrm{~g}$ glucose-C/d and $160 \mathrm{~g} \mathrm{CO}-\mathrm{C} / \mathrm{d}$. Ratios of SR of infused and secondary-pool metabolites indicated transfers of radioactivity from threonine-C to glucose- $\mathrm{C}$ and $\mathrm{CO}_{2}-\mathrm{C}$ which account for approximately $0.33 \%$ of the glucose-C and $0.12 \%$ of the $\mathrm{CO}_{2}-\mathrm{C}$. Further calculations and interpretations are made in the discussion.

\section{Expt 2}

Results obtained in Expt 2 are given in Table 3. Daily intake of Agrostis festuca varied little during the period of the experiment, though food was refused during the period of phloridzin infusion by two sheep (i.e. nos. 74 and 12). Plasma glucose concentration differed significantly between sheep $(P<0.05)$ and was significantly lower in all sheep when phloridzin was infused $(P<0.01)$. Glucose ILR was increased $(P<0.001)$ by $27 \pm 1.8 \%$ during phloridzin infusions. Glucose excretion in the urine occurred at measurable levels only during phloridzin infusion. The amount of glucose passed in urine $(9 \cdot 8 \pm 0.24 \mathrm{~g} \mathrm{C} / \mathrm{d})$ was greater $(P<0.001)$ than the increase in glucose ILR estimated by isotope dilution $(7 \cdot 0 \pm 0.48 \mathrm{~g} \mathrm{C} / \mathrm{d})$. There was no consistent effect of phloridzin infusion upon the proportional transfer of ${ }^{14} \mathrm{C}$ from glucose to $\mathrm{CO}_{2}$.

\section{Expt 3}

Both sheep consumed all feed in all phases of the experiment (intakes $648 \pm 25 \mathrm{~g} / \mathrm{d}$ ) except when sheep no. 12 refused feed over a period of $6 \mathrm{~h}$ during phloridzin infusion in the period in which $\mathrm{CO}_{2}$ ILR was measured.

The results for the ILR for threonine, glucose and $\mathrm{CO}_{2}$ and the transfer of $\mathrm{C}$ between 
Table 3. Expt 2. Effect of phloridzin (20 mg priming dose; $9.7 \mathrm{mg} / \mathrm{h}$ infusion) on plasma glucose and blood carbon dioxide kinetics and urinary glucose loss in sheep given Agrostis festuca

\begin{tabular}{|c|c|c|c|c|c|c|c|c|}
\hline \multirow{2}{*}{$\begin{array}{l}\text { Sheep no.... } \\
\text { Treatment*.. }\end{array}$} & \multicolumn{2}{|c|}{443} & \multicolumn{2}{|c|}{74} & \multicolumn{2}{|c|}{9} & \multicolumn{2}{|c|}{12} \\
\hline & $-P$ & $+P$ & $-P$ & $+P$ & $-\mathbf{P}$ & $+\mathbf{P}$ & $-\mathrm{P}$ & $+\mathrm{P}$ \\
\hline \multicolumn{9}{|l|}{ Digestible organic } \\
\hline matter intake & \multicolumn{2}{|c|}{$\begin{array}{c}214 \\
(\text { SE } 28)\end{array}$} & \multicolumn{2}{|c|}{$\begin{array}{c}220 \\
(\mathrm{SE} 32)\end{array}$} & \multicolumn{2}{|c|}{$\begin{array}{c}214 \\
(\text { SE } 17)\end{array}$} & \multicolumn{2}{|c|}{$\begin{array}{c}232 \\
(\mathrm{sE} 20)\end{array}$} \\
\hline $\begin{array}{l}\text { Plasma-glucose } \\
\text { concentration (mmol) }\end{array}$ & $2 \cdot 90$ & $2 \cdot 65$ & $3 \cdot 35$ & $3 \cdot 18$ & $2 \cdot 87$ & $2 \cdot 46$ & $3 \cdot 12$ & $2 \cdot 58$ \\
\hline $\begin{array}{l}\text { [U-14 } \mathrm{C} \text { ]glucose infusion } \\
\text { rate }(\mathrm{nCi} / \mathrm{min})\end{array}$ & \multicolumn{2}{|c|}{$160 \cdot 1$} & \multicolumn{2}{|c|}{158.2} & \multicolumn{2}{|c|}{152.7} & \multicolumn{2}{|c|}{$151 \cdot 8$} \\
\hline $\begin{array}{l}\text { Plasma glucose SR } \\
(\mathrm{mCi} / \mathrm{g} \mathrm{C})\end{array}$ & $8 \cdot 16$ & 6.61 & $9 \cdot 18$ & $7 \cdot 11$ & 9.95 & 7.90 & $8 \cdot 42$ & $6 \cdot 44$ \\
\hline Glucose ILR ( $\mathrm{g} \mathrm{C} / \mathrm{d}$ ) & $28 \cdot 3$ & 34.8 & 24.7 & $32 \cdot 2$ & $22 \cdot 1$ & 27.8 & $25 \cdot 9$ & $33 \cdot 8$ \\
\hline $\begin{array}{l}\text { Blood } \mathrm{CO}_{2} \mathrm{SR} \\
(\mathrm{mCi} / \mathrm{g} \mathrm{C})\end{array}$ & 0.74 & 0.55 & 0.66 & 0.63 & 0.51 & 0.46 & 0.50 & 0.39 \\
\hline Percentage $\mathrm{CO}_{2}$ from & & & & & & & & \\
\hline glucose-C & 9.07 & $8 \cdot 37$ & $7 \cdot 24$ & 8.86 & $5 \cdot 52$ & 5.79 & 5.95 & $6 \cdot 01$ \\
\hline Urinary glucose $(\mathrm{g} \mathrm{C} / \mathrm{d})$ & ND & $9 \cdot 8$ & ND & $9 \cdot 4$ & ND & $9 \cdot 8$ & ND & $10 \cdot 6$ \\
\hline
\end{tabular}

* $-\mathrm{P}$, before phloridzin infusion; $+\mathrm{P}$ during 8 th-12th $\mathrm{h}$ of phloridzin infusion. SR, specific radioactivity. ILR, irreversible loss rate. ND, not detectable.

these metabolites obtained in the period before phloridzin infusion were consistent with those from Expt 1 (Table 4). Similarly, the effects of phloridzin (in this experiment infused at a greater dose rate than in Expt 2) on glucose metabolism were consistent with those observed in Expt 2. Glucose concentration in the plasma was significantly $(P<0.05)$ depressed during each of the three phloridzin infusions for each sheep; glucose ILR was increased by $30-35 \%$ in both sheep, i.e. from 30 to $40 \mathrm{~g} \mathrm{C} / \mathrm{d}$; and urinary glucose loss increased from undetectable levels to $10-12 \mathrm{~g} \mathrm{C} / \mathrm{d}$ during the infusion. Again, the loss of glucose via the urine exceeded the increase in glucose ILR. Phloridzin infusion had no effect on threonine ILR and no free threonine radioactivity was found in the urine. ILR of $\mathrm{CO}_{2}$ measured through the plasma compartment was increased in both sheep during phloridzin infusion.

Table 4 also gives the transfer quotients of ${ }^{14} \mathrm{C}$ from threonine, glucose and $\mathrm{CO}_{2}$ to secondary pools. Threonine ${ }^{14} \mathrm{C}$ appeared to contribute approximately $0.31 \%$ of glucose-C passing through the plasma pool. This contribution was increased by $10-20 \%$ when phloridzin was infused. Threonine ${ }^{14} \mathrm{C}$ appeared to contribute approximately $0 \cdot 16 \%$ of the $\mathrm{CO}_{2} \mathrm{ILR}$, and this was increased by approximately $40 \%$ during phloridzin infusion.

\section{Three-pool model construction}

Data from Expts 1 and 3 (see Tables 2 and 4) were used to develop a three-pool, open-compartment model of the type shown in Fig. 1. Values obtained for the $\mathrm{C}$ transfers between threonine, glucose and $\mathrm{CO}_{2}$ for sheep nos 443 and 74 in Expt 1 and for sheep nos 9 and 12 before and during infusion of phloridzin in Expt 3 are presented in Table 5. 
Table 4. Expt. 3. The effects of phloridzin (20 $\mathrm{mg}$ priming dose; $17 \cdot 8 \mathrm{mg} / \mathrm{h}$ infusion) on plasma-glucose concentration; on irreversible loss rate (ILR) of glucose-C, threonine-C and $\mathrm{CO}_{2}-\mathrm{C}$ in blood; on transfer quotients between threonine, glucose and $\mathrm{CO}_{2}$; and on urinary glucose loss in two sheep given Agrostis festuca ( $250 \mathrm{~g}$ digestible organic matter/d)

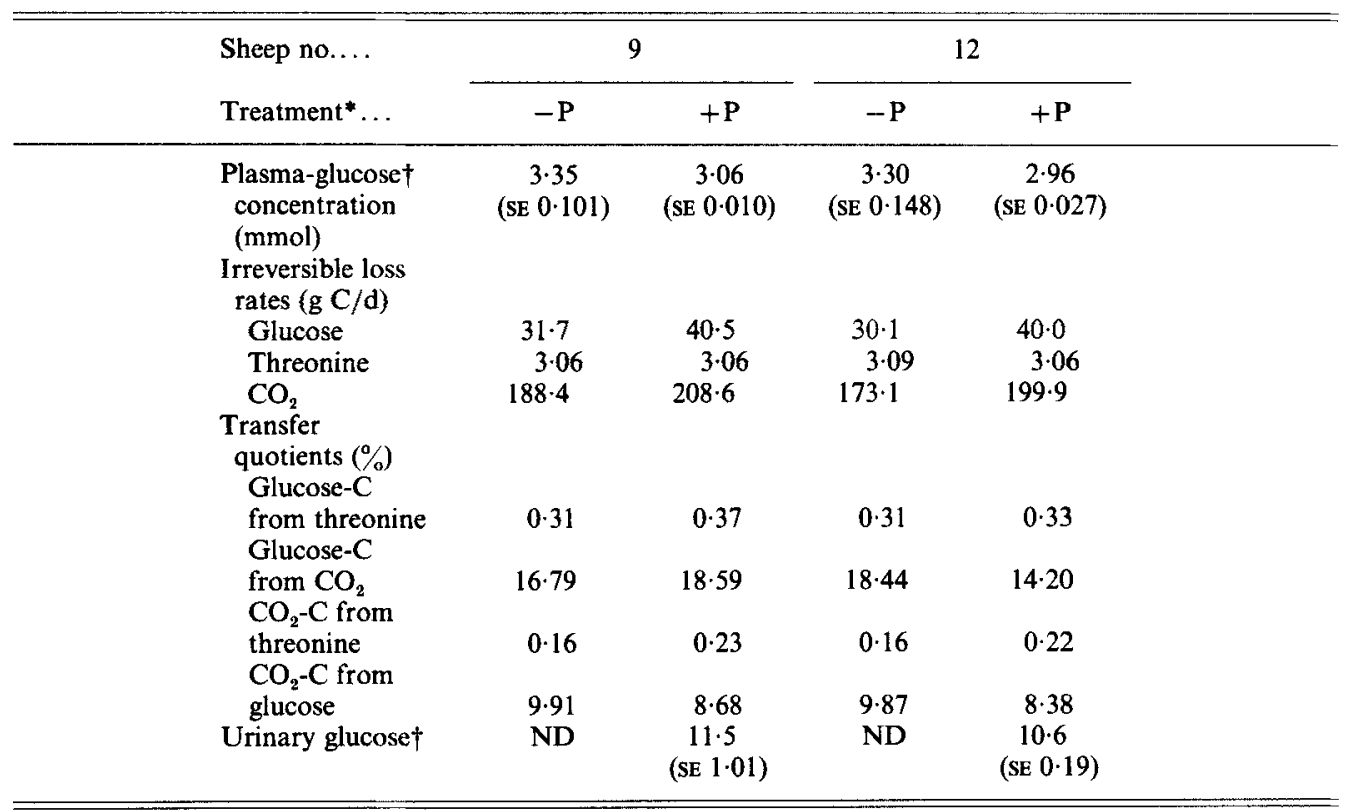

* $-P$, before phloridzin infusion; $+P$, during 8 th- 12 th $h$ of phloridzin infusion.

$\dagger$ Mean of values obtained on the three separate occasions, i.e. when (i) glucose, (ii) threonine and (iii) $\mathrm{CO}_{2}$ ILR were determined.

ND, not detectable.

Table 5. Calculated values for carbon transfers $(\mathrm{g} C / \mathrm{d})$ between threonine, glucose and carbon dioxide as reflected in the circulating blood, and derived from results presented in Tables 2 and 4 according to the model shown in Fig. 1

\begin{tabular}{|c|c|c|c|c|c|c|c|c|c|c|c|c|c|c|}
\hline \multirow{2}{*}{$\begin{array}{l}\text { Expt. } \\
\text { no.* }\end{array}$} & \multirow{2}{*}{$\begin{array}{c}\text { Sheep } \\
\text { no. }\end{array}$} & \multirow{2}{*}{$\begin{array}{l}\text { Treat- } \\
\text { ment }\end{array}$} & \multicolumn{12}{|c|}{ Component, carbon transfer rates $(\mathrm{g} \mathrm{C} / \mathrm{d})$} \\
\hline & & & $a$ & $b$ & $c$ & $d$ & $e$ & $f$ & $g$ & $h$ & $i$ & $j$ & $k$ & $l$ \\
\hline 1 & 443 & - & $2 \cdot 8$ & 17.8 & $3 \cdot 0$ & $25 \cdot 1$ & $144 \cdot 4$ & $151 \cdot 9$ & 0.09 & 0 & 0.13 & 0 & $13 \cdot 1$ & $5 \cdot 6$ \\
\hline 1 & 74 & - & 2.9 & 16.5 & $3 \cdot 2$ & $24 \cdot 1$ & 150.8 & 158.7 & 0.09 & 0 & 0.18 & 0 & 12.8 & $5 \cdot 1$ \\
\hline 3 & 9 & $-\mathbf{P}$ & 2.7 & $13 \cdot 3$ & $3 \cdot 1$ & $26 \cdot 7$ & $172 \cdot 4$ & $186 \cdot 2$ & 0.09 & 0 & 0.25 & 0 & 19.0 & $5 \cdot 4$ \\
\hline 3 & 9 & $+P$ & 2.5 & $23 \cdot 3$ & $3 \cdot 1$ & $33 \cdot 3$ & 193.3 & $204 \cdot 2$ & $0 \cdot 13$ & 0 & 0.42 & 0 & 17.8 & 7.6 \\
\hline 3 & 12 & $-\mathbf{P}$ & $2 \cdot 8$ & 13.2 & $3 \cdot 1$ & 24.9 & 158.6 & $170 \cdot 7$ & 0.09 & 0 & 0.23 & 0 & 17.4 & 5.6 \\
\hline 3 & 12 & $+\mathbf{P}$ & 2.5 & $23 \cdot 5$ & $3 \cdot 1$ & 34.6 & 184.9 & 196.6 & 0.12 & 0 & 0.39 & 0 & 17.0 & 5.7 \\
\hline
\end{tabular}

* For details, see pp. 374 and 375.

$\dagger-\mathrm{P}$, before phloridzin infusion; $+\mathbf{P}$, during 8 th -12 th $\mathrm{h}$ of phloridzin infusion. 


\section{DISCUSSION}

As well as needing to synthesize protein, sheep also have a physiological requirement for glucose. When they are given roughage diets this glucose must be met almost entirely by processes of gluconeogenesis (Lindsay, 1959; Leng, 1970), and the potential precursors of this glucose include amino acids whose $\mathrm{C}$-chains are catabolized through pathways leading to a net gain of intermediates in the tricarboxylic acid cycle or the glycolytic pathway. Threonine is one such amino acid. Catabolism of threonine may proceed through at least two major pathways, the dehydratase pathway (Sayre \& Greenberg, 1956) and the aldolase pathway (Lin \& Greenberg, 1954), and the intermediates yielded may contribute C to pathways leading to glucose synthesis. The resynthesis of threonine after the first step in catabolism by either pathway is not possible, and so threonine-C committed to these pathways will be distributed into other metabolites such as glucose, or will be oxidized.

While threonine may be potentially gluconeogenic, the extent to which de novo synthesis of glucose from threonine occurs in sheep has not been determined quantitatively under any set of nutritional or physiological circumstances. If the fate of threonine is determined by conditions other than threonine supply this could involve the following factors: energy supply and energy demand; the rate of gluconeogenesis from alternative sources and the glucose demand; and the availability of threonine relative to the potential rate of glucose synthesis. Information on the factors which affect the quantitative distribution of threonine into catabolic pathways will lead to a better understanding of the capacity of the animal to manipulate this apparently scarce nutrient, particularly in conditions where the availability of gluconeogenic precursors also presents problems. The studies reported in the present and subsequent paper (MacRae \& Egan, 1983) have concentrated on sheep whose nutritional or physiological state or both were likely to cause their glucose economy and their amino acid availability to be critical. Thus, in the present experiments the animals were in negative energy and $\mathrm{N}$ balance, with their glucose production rates unlikely to be more than that which was essential for normal metabolic function. With such conditions it was hoped that when phloridzin was infused and glucose (approximately $30 \mathrm{~g} / \mathrm{d}$ ) was passed in the urine, the animal's requirement for providing this extra glucose would place its gluconeogenic processes in a critical state.

\section{Technical considerations}

Assuming that steady-state kinetics are maintained throughout an experiment, then the ILR of each metabolite studied is the rate at which radioactive tracer and the tracee with which it is mixed leaves the sampled pool and is replaced by non-radioactive tracee from either exogenous or endogenous sources. Such values will represent an underestimate of the 'total entry rate' of the metabolite into the sampled pool where there is re-entry from compartments not in rapid equilibrium with the primary compartment. Ideally, the transfer of ${ }^{14} \mathrm{C}$ from a substrate to a product should be estimated from the specific activities of these metabolites at the intercellular site of the metabolism. However, in the intact animals these values cannot be determined for each tissue, indeed the actual sites are sometimes unknown. The varying contributions of the different tissues are approximated by comparison of the substrate and product SR in the more readily accessible compartment in which substrate and product are both transported. It is accepted that although the blood bicarbonate compartment, and the plasma glucose and free threonine compartments, represent key contributors to the pools of bicarbonate glucose and threonine in the body, they do not exchange freely with all metabolically important compartments. This limitation means that in relatively short-term experiments performed on living animals there are aspects of metabolism which are concealed in tracer kinetic analyses so that interpretation of such 
results must be cautious. Notwithstanding, the technique is capable of giving valuable information, especially in situations where different measurements need to be made on the same animal with minimal physiological or surgical interference.

One problem associated with obtaining the primary measurements required to calculate models such as that given in Fig. 1 is that measurement of the ILR and transfer quotients all require ${ }^{14} \mathrm{C}$-labelled isotopes and so necessitates several separate experiments to be carried out over a number of days. Wilson et al. (1981) have reported that day-to-day variation in variables such as glucose ILR can be considerable; the coefficient of variation on glucose ILR measured on three separate occasions in wether sheep was as high as $22 \%$ in one case reported. In this experiment it was decided to adopt the approach of using a tritium-labelled glucose tracer as a covariant which was infused along with the ${ }^{14} \mathrm{C}$-precursor and the ${ }^{14} \mathrm{C}$-glucose infusion. This provided a basis for correction of ILR and transfer quotients to a common base between days; corrections made were never greater than $5 \%$.

\section{Threonine metabolism}

If, as argued, the apparent absorption of threonine in these sheep was approximately $1 \mathrm{~g}$ $\mathrm{C} / \mathrm{d}$, then the threonine ILR was three times this value, indicating entry of at least $2 \mathrm{~g}$ threonine-C from protein breakdown.

Catabolism of threonine can yield intermediates which are potentially gluconeogenic (Krebs, 1964). However, in the lactating cow, calculations based on the values of Black et al. (1968) suggest that only $2.5 \%$ of the threonine-C traversing the free-plasma pool was converted to glucose-C in $48 \mathrm{~h}$ after a single injection of $\left[{ }^{14} \mathrm{C}\right]$ threonine. Unfortunately, lack of values for threonine and glucose flux rates in that study makes this estimate tenuous. In rats, Bloxham (1975) reported little increase in in vivo hepatic glucose production in response to increased inputs of threonine within the physiological range. Glucose production was enhanced in isolated sheep hepatocytes when high substrate levels of threonine were added to the medium (Morton et al. 1977), but threonine-C was not shown to be the direct source of the $\mathrm{C}$ in the glucose produced. In sheep treated with phloridzin in order to recover substantial amounts of glucose in urine, ${ }^{14} \mathrm{C}$ from $\left[\mathrm{U}-{ }^{14} \mathrm{C}\right]$ threonine was shown to be present in glucose, accounting for approximately $1 \%$ of threonine-C (Morton et al. 1977). However, the effect of phloridzin on gluconeogenesis from amino acids such as threonine was not examined. For the Agrostis-fed wether our estimates based on ILRs and transfer quotients within the time-scale of these experiments indicate that the rate of incorporation in vivo of $\mathrm{C}$ from circulating threonine into glucose is very low, accounting for only $3 \%$ of the threonine-C ILR or, conversely, $0 \cdot 3 \%$ of the glucose-C produced. Approximately $45-60 \%$ of the glucose produced was oxidized to $\mathrm{CO}_{2}$ in these sheep and so this suggests that approximately $1.2-1.6 \%$ of the threonine-C ILR traversed the glucose pool and entered the pathways leading to loss of carbon via $\mathrm{CO}_{2}$. A further $2.5-6.5 \%$ of threonine-C irreversibly lost appeared in $\mathrm{CO}_{2}$ through pathways of catabolism involving intermediates not leading to glucose synthesis.

It follows from the previously mentioned calculations that $90 \%$ of the threonine-C (i.e. $2.7 \mathrm{~g}$ out of the $3.0 \mathrm{~g} / \mathrm{d}$ lost from the plasma-free threonine pool) did not appear as circulating glucose or $\mathrm{CO}_{2}$. However, these sheep lost weight during the experiment, receiving lower energy intakes than required for maintenance. Therefore, each day an amount of threonine at least equal to that absorbed must be catabolized or otherwise lost, since no net protein synthesis was possible. Thus, while at least $1 \mathrm{~g}$ of the $3 \mathrm{~g}$ threonine-C/d irreversibly lost must be catabolized in some way, only one-third of this amount can be accounted for as appearance of ${ }^{14} \mathrm{C}$ in glucose or $\mathrm{CO}_{2}$ during the time course of the experiment. These comparisons indicate that a major proportion of circulating threonine enters into non-catabolic pathways from which, with a delay time which exceeds the 
duration of each of the current experiments, there is a significant re-entry of metabolites into catabolic or excretory pathways which are not entered directly by circulating free-threonine. The metabolites involved cannot include circulating free-threonine. Such 'hideaway' metabolites probably include newly synthesized proteins with a large pool size and slow turnover time. The ${ }^{14} \mathrm{C}$-label may be incorporated into these proteins as threonine itself or intc other amino acids, the $\mathrm{C}$ of which is derived from threonine. Sundry other derived metabolites, including glycine, may remain out of circulation for a period or be lost via routes other than oxidation. Further work is necessary to determine the nature and magnitude of these postulated intermediates carrying threonine- $\mathrm{C}$, the distribution of pools of these metabolites, the kinetics of their behaviour and the extent to which they are gluconeogenic. The significance of this aspect of further study has been indicated elsewhere (MacRae \& Egan, 1980).

\section{Influence of glucose drain on threonine metabolism}

That the pattern of metabolism of threonine was affected by altering the glucose economy of the animal is evident from the results obtained when phloridzin was infused (see Table 5). In both Expts 2 and 3 there was substantial loss of glucose in the urine. The glucose ILR increased by $10 \mathrm{~g} \mathrm{C} / \mathrm{d}(30 \%)$, which was slightly less than the rate at which glucose was lost in the urine. In Expt 3, that fraction of glucose-C representing production from sources other than threonine and bicarbonate was increased by 6.6 and $9.7 \mathrm{~g} / \mathrm{d}$ respectively in sheep nos. 9 and 12 (Table 5, transfer rate $d$ ), and glucose-C oxidized to $\mathrm{CO}_{2}$ was decreased by 1.2 and $0.4 \mathrm{~g} / \mathrm{d}$ respectively (transfer rate $k$ ). $\mathrm{CO}_{2}-\mathrm{C}$ production from $\mathrm{C}$ sources other than glucose was increased by 21 and $26 \mathrm{~g}$ respectively (transfer rate $e$ ). In these somewhat aphysiological circumstances there was no apparent change in threonine ILR, but there was respectively a 44 and $33 \%$ increase in the transfer of threonine-C to glucose (transfer rate $g$ ), accounting for $4 \%$ as opposed to $2.9 \%$ of the threonine-C ILR. There was also a $68 \%$ increase in transfer of threonine- $\mathrm{C}$ to $\mathrm{CO}_{2}$ (transfer rate $i$ ) accounting for $13 \%$ rather than $8 \%$ of the threonine-C ILR. Because threonine-C ILR was not increased (see Table 4), this implied a redirection of the threonine-C drawn from the free-plasma pool away from protein synthesis and from the formation of other products not catabolized. The conditions of the experiment were acute, and these metabolic responses to phloridzin treatment, involving a large urinary glucose loss, involved not only increased glucose ILR but also a reduction in plasma-glucose concentration and hence the size of the plasma-glucose pool.

These experiments, though indicating a change in the pattern of threonine metabolism with altered glucose metabolism, may not provide an adequate test of the extent of the sheep's ability to alter the rate and pattern of threonine metabolism and of glucose production from threonine in the long-term or in more normally-experienced physiological conditions. Because of this, further studies were undertaken with pregnant (MacRae \& Egan, 1983) and lactating (A. R. Egan \& J. C. MacRae, unpublished results) ewes where adaptation to altering requirements for amino acids and glucose might be expected to be more complete.

A. R.E, would like to thank the Agricultural Research Council for financial assistance from the Underwood Fund.

\section{REFERENCES}

Black, A. L., Egan, A. R., Anand, R. S. \& Chapman, T. E. (1968). Isotope Studies on the Nitrogen Chain, p. 247. Vienna; International Atomic Energy Agency.

Bloxham, D. L. (1975). Am. J. Physiol. 229, 1718.

Egan, A. R. (1980). Proc. Nutr. Soc. 39, 79.

Egan, A. R. \& MacRae, I. C. (1978). Proc. Nutr. Soc. 37, 15A. 
Egan, A. R. \& Walker, D. (1975). Proc. 3rd Wld Conf. Anim. Prod. p. 551.

Fennessy, O. (1976). Post-ruminal amino acid supplementation to sheep fed roughage diets. PhD Thesis, University of Adelaide.

Huggett, A. St G. \& Nixon, D. A. (1957). Lancet 273, 368.

Jones, G. B. (1965). Analyt. Biochem. 12, 249.

Krebs, H. A. (1964). In Mammalian Protein Metabolism, vol. 2, p. 125 [H. N. Morris and J. B. Allison, editors]. London and New York: Academic Press.

Leng, R. A. (1970). Adv. vet. Sci. 14, 209.

Leng, R. A. \& Leonard, G. J. (1965). Br. J. Nutr. 19, 469.

Lin, S. E. \& Greenberg, D. M. (1954). J. gen. Physiol. 38, 181.

Lindsay, D. B. (1959). Vet. Rev. 5, 103.

MacRae, J. C. \& Egan, A. R. (1980). Publ. Eur. Ass. Amin. Prod. no. 26, p. 421.

MacRae, J. C. \& Egan, A. R. (1983). Br. J. Nutr. 49, 385.

MacRae, J. C., Milne, J. A., Wilson, S. \& Spence, A. M. (1979). Br. J. Nutr. 42, 525.

MacRae, J. C., Ulyatt, M. J., Pearce, P. D. \& Hendtlass, J. (1972). Br. J. Nutr. 27, 39.

MacRae, J. C. \& Wilson, S. (1978). Int. J. appl. Rad. Isotopes 29, 191.

Morton, J. L., Buttery, P. J. \& Lindsay, D. B. (1977). Proc. Nutr. Soc. 36, 20 A.

Nolan, J. V., Norton, B. W. \& Leng, R. A. (1976). Br. J. Nutr. 35, 127.

Sayre, F. W. \& Greenberg, D. M. (1956). J. biol. Chem. 220, 787.

Wilson, S., MacRae, J. C. \& Buttery, P. J. (1981). Res. vet. Sci. 30, 205. 